Portland State University

PDXScholar

\title{
Growing Against the Grain: Confronting White Supremacy and Patriarchy in Gardens in the Dunes
}

Andre Cole

Portland State University

Follow this and additional works at: https://pdxscholar.library.pdx.edu/honorstheses

Let us know how access to this document benefits you.

\section{Recommended Citation}

Cole, Andre, "Growing Against the Grain: Confronting White Supremacy and Patriarchy in Gardens in the Dunes" (2018). University Honors Theses. Paper 630.

https://doi.org/10.15760/honors.641

This Thesis is brought to you for free and open access. It has been accepted for inclusion in University Honors Theses by an authorized administrator of PDXScholar. Please contact us if we can make this document more accessible: pdxscholar@pdx.edu. 
Andre Cole

Honors Senior Thesis

$1 / 14 / 18$

Growing Against the Grain: Confronting White Supremacy and Patriarchy in Gardens in the Dunes

\section{Introduction}

Eight years after publishing Almanac of the Dead, her revolutionary work that literally started a revolution in Chiapas, indigenous author Leslie Marmon Silko was looking for an escape from accusations that her writing was 'too political'. She decided for her next novel that she would instead channel her fascination with gardening into an apolitical work, so she "Started writing, but then it wasn't too long before I realized how very political gardens are. Though my conscious self had tried to come up with an idea for a non-political novel, I had actually stumbled into the most political thing of all? How you grow your food, whether you eat, the fact that the plant collectors followed the Conquistadors," (Arnold and Silko, 3). What resulted was Gardens in the Dunes, an artful work of historical fiction that blended gardening techniques with tribal sovereignty, femininity with fire starting, and a child-friendly adventure narrative with a gruesome metanarrative of genocide. It is not a short read, by any metric, but each word is devoted towards either establishing the context of oppression the protagonists face and the methods through which they receive their salvation from said oppression; chief among these methods of personal escape is the cultivation of gardens of various lush descriptions. This novel 
not only reveals these methods to the reader, but also outlines how to make each method work through parallel character studies, if one wished to find inspiration on how to resist or oppose the current rising tide of overprivileged and undersexed white men hoping to "Make America Great Again" (in the sense that Wounded Knee was a great moment), Gardens would not be a terrible place to look. But first, we're going to need to explore the plot, the history, and the vocabulary necessary to make these contemporary connections.

\section{Terms and Conditions}

The story begins in the late 1800's with two sisters, Indigo and Sister Salt, reveling in a luxurious rainfall in their desert home. The novel extends backwards and forwards in time from this moment of environmental bliss, revealing that these two girls are the sole survivors of the long-term genocide of their tribe, the Sand Lizards. Originally, they were raised by their mother and her mother, Grandmother Fleet; however their mother is taken away by the ominous "indian police" and Grandmother Fleet succumbs to old age just after passing on to the girls the ways of tending to "The Old Gardens", a place of physical and spiritual nourishment for their people. Eventually, while observing the Ghost Dancing ritual in the town of Needles, the Indian Police catch up with them and the two are separated: Sister Salt is sent to a reservation nearby while Indigo is sent to an Indian school in Riverside, California. Indigo refuses to undergo the indoctrination of the school and escapes, only to find herself temporarily adopted by a white couple living nearby. The wife of the couple, Hattie, is a former theology scholar disillusioned with academia after her thesis is rejected for heretical views and a classmate of hers sexually assaults her; her story arc from that background context is her rediscovering herself through her 
brief marriage to Edward. Edward for his part is a horticulturalist, but his respect of plants only extends as far as he can monetize his samples: one such journey before meeting Indigo resulted in his colleagues burning down the rainforest before competition can take the same blue orchids they were collecting, leaving him behind and him falling and breaking his leg. Through well-meaning in their care of Indigo, they delay her journey home significantly by taking her to Upstate New York and eventually to Europe while continuing her "education". However, several factors inhibit their ability to train Indigo into westernized ideals: Indigo herself recontextualizes their lessons through her own indigenous lens constantly, Hattie herself begins to question her Judeo-Christian ideals after encountering a will-o'-wisp in an English Garden, and Edward gets caught up in further business schemes involving smuggling Italian citrons back to America and collaborating with a shady Australian Doctor to mine meteorite irons. While all of this is happening, a couple of chapters and sections are devoted to updating us on Sisters Salt's condition: she develops a business/sexual relationship with Big Candy, a chef on a local dam-building project, wherein she and another pair of displaced indian sisters brew beer, clean laundry, and prostitute themselves on behalf of the workers of the dam. Salt becomes pregnant, but she is ok with this due to the relaxed sexual mores of the Sand Lizards. However, a different rift begins to open up between her and Big Candy as he plans to open a restaurant in Denver, which is too far for her to wait for Indigo to find her. This rift intensifies when Salt gives birth prematurely, and Candy doubts the odds of survival for the child. In the end, each of these plotlines comes to some sort of head: Candy's nest egg is stolen, Edward is caught stealing the citrons which leads to Hattie divorcing him, and Indigo frequently loses or intentionally abandons her valise of plant seeds which she has gathered on her unusual odyssey. In spite of 
this, the resolution of the novel is quite positive: Indigo and Salt are reunited in the Old Gardens, with the addition of Salt's baby and the support of both of the female social circles the girls have gathered in their separation. The gardens, while vandalized by some unknown enemy, are shown to be on the road to recovery thanks to the girl's renewed attention. In spite of the violence inflicted upon them by various colonial interests, the tribe will endure in the seclusion of their ancestral home. As a work of historical fiction, Gardens attempts to balance historical fact with a progressive fictional narrative, and thus it would do well to briefly discuss the context of settler violence and responses to it, namely the Ghost Dance Movement.

The atrocity that was Wounded Knee is heavily obscured in American media, to the point that many who do not seek knowledge of it believe it to be one of many "Indian wars' of the era. In truth, the bloodshed was instigated by an innocent round-dance branded with a misleadingly ominous name: “'Ghost Dance' is the name usually applied to Jack Wilson's religion, because the prophet foresaw the resurrection of the recently dead with the hoped-for renewal of the earth" (Kehoe, 9). Jack Wilson (a.k.a. Wovoka) advocated for a united, peaceful movement and promised in return a reunion with lost loved ones and environmental renewal to a time before the colonists. This is depicted in Gardens, but the novel goes a few steps further by suggesting that the Holy Mother and Messiah performed miracles during the dance such as summoning snow and speaking several languages at once (Silko, 33). But what is depicted with vile accuracy is the response of the US government to such a numerous gathering of Indians: constant disruption through the militant force of Indian Police. Were Indigo and Salt not protected by the needs of the plot, perhaps they would have been caught in the crossfire on December 29th, 1890, when a 
misfired gun lead to 25 dead soldiers and 153 murdered Lakota (Kehoe, 33). The grim backdrop of this event colors all interactions the Sand Lizard girls endure, for at any time their fate could have been cut short by a trigger-happy soldier. And the threat of such hostile white men is omnipresent in the story proper.

While there is no one overarching enemy over the duration of the novel, the conflicting forces are overall white-coded, male-coded, and uncompromisingly colonist. Whether it is the long-past murder of the girl's grandfather or the cultural genocide that is Indian schools, the introduction to white society that Salt and Indigo receive represents a clear and merciless threat to themselves and their traditional way of life. Named white men in the book are not as malevolent as the organizational colonization, however they are typically ruled by their own avarice and internalized superiority. Edward never states that he feels Indigo is his inferior, but he clearly thinks as much when we get a look inside of his head; beyond that, his form of horticulture is exploitative of both the local communities that have attached symbolic significance to the plants he steals and the plants themselves. Meanwhile, while Foreman Wiley has an amicable relationship with Big Candy, he prioritizes his own desire to keep Candy's cooking skills close at hand over Candy's dream in Denver. Finally, there are several characters who are characterized entirely as untouchable rapists: Mr. Hyslop, the Australian Doctor, and the coachman from Albuquerque at separate points in the novel sexually assault Hattie as if she is somehow marked for molestation. None of these men are directly punished for their actions, and when Hattie confronts this flaunting of rape culture she is told her anxieties are unfounded and/or there is nothing that can be done. In light of these individual flawed men being a part of the 
pre-established dominant culture of violence against women and minorities, it is not surprising that each of the subjugated parties form their own methods of fighting the system; what is surprising is how those methods vary based on the standings of the individuals within the dominant American, Eurocentric paradigm. In total, these men are primarily concerned with total domination over the spaces they inhabit and the bodies of the things living there: from other "lesser" humans to plants to the very stones in the Earth. And yet, by the end of the novel, the oppressed have outlived and outlasted the oppressors. How?

The answer lies in the sociological theories of Michel de Certeau, who defined responses to oppressive dominant forces (for our purposes, colonization) as continuing one's daily existence in ways that subvert the will of the imposed paradigm. In defining his theory of everyday responses to power, De Certeau distinguishes between "resistance" and what he calls “opposition." If resistance is exemplified in pitched battles against enemies, or escape to spaces outside of power's reach, then "opposition" entails minor, everyday pushback against the power Structure: Resistance is clear in the narrative of gardens, so much so that the example given feels as if it is a description of Grandma Fleet's daily gardening and foot-dragging, earth-connected walks:

De Certeau uses the example of Spanish colonizers who imposed their culture on the indigenous Indians (the users, non-makers). The Indians responded by transforming rituals, representations and laws imposed on them even as they were subjected to Spanish colonization. The outwardly assimilated Indians thus subverted the norms without 
rejecting them. They deflected the dominance of the Spanish and escaped it without actually leaving it (Certeau xiii) (Burton, 58).

Opposition, in other words, is the practice of directly confronting dominant culture by way of personal practices that, while on the surface non-confrontational, are socially subversive in practice. A grim example of this, or at least in outcome, is the Ghost Dance: the U.S. military, in spite of the nonviolence and the judeo-christian imagery of the event, lash out at what is perceived as a counter-army of indian men, women, and children. And yet, this dance is formative to Sister Salt and Indigo, who from that day on see the dance as a sacred act that bridges all linguistic and social divides. De Certeau emphasizes the oppositional function of storytelling and other cultural practices: "The function of the stories is to de-authorize an establishment, to displace or transcend limits and to set up an opposition within the closed field as well as to authorize the subject with social actions to mark out boundaries and open a field for themselves (125)" (Burton, 76). Within opposition, even fewer options for social subversion are available: the subject has physical or professional limitations that prevent them from overt acts of resistance. Thus, acts of opposition are more calculated and guarded from their end goal; for example, Hattie engages in what is recognizable to the informed as paganism far ahead of her time but what her peers would instead attribute to collecting souvenir rocks and figurines of Roman Goddesses. Far from the accusations of heresy she garnered for her apocrypha-thesis, this blatant act of heathenism is unknown to any critics she may face. While it may seem to an outsider that opposition can never be as powerful as the subversive power of resistance, there are times and places where opposition fulfills a key role for individuals caught in both the dominant culture of American colonialism and the various marginalized groups impacted by it. The main 
narrative of Gardens in the Dunes is characters finding their own forms of resistance or opposition, sometimes transitioning rapidly between categories as their situation calls for it. Drawing on this particular ideological connection is not unheard of, but often the stakes of such meaningful daily action are often spiritualized: "Seen in the light of Conley's perceptions and de Certeau's theories, through the classic Nineteenth-century novel form, at its core, Gardens in the Dunes demonstrates Silko's understanding of the differences between secular and sacred uses of story" (Cummings, 86). Gardens may present itself as an apolitical, secular work of historical fiction but once a critical eye is pointed towards the less conformist acts of Indigo, Salt, Hattie, Martha, Vedna, and so on a pattern of religiously-charged cultural subversion reveals itself. To merely observe this trend is an act of opposition, to read past the false expectation that a book about gardening is simply that.

\section{Resist and Bite}

Grandma Fleet is an important character for her impact on the Sand Lizard Sisters, as her life and death exemplify the Native women's commitment to of resistance. As the soul keeper of their tribal heritage, she recounts to the girls how "Long ago, when the Apaches used to raid the Sand Lizards' villages, the Sand Lizards fought back fiercely until they were beating the Apache, but then, instead of fighting to the end to crush the Apaches and make them slaves the way other tribes did, the Sand Lizard people used to stop fighting and let the Apache get away. Other tribes called them crazy for this, but the Sand Lizards didn't have much use for slaves; they were just more hungry mouths to feed, and slaves had to be watched all the time," (Silko, 50). The Sand Lizard tribe had figured out what the Apache, and later the United States would need to learn: 
that human subjugation is a zero-sum game. Instead, their military might began and ended with self-defense; and though this method of "Drive them off and Let them go" did not work out so well with the United States Army, that fighting spirit manifested in other ways. In a situation where military resistance proves impossible, opposition becomes the only viable option. Another way that Grandma Fleet passes on the unique ways of the tribe is in her seed gathering, specifically searching out seeds from unfamiliar plants. To say she would die for such rarities would be a morbid understatement: “The girl's grandmother is a master of appropriation, turning the trash of colonialism into the sustenance of life outside of it. Her living memorial, in fact, is the apricot trees whose seeds she has gleaned from the trash mounds of Needles, which grow over her grave (Silko, 24)," (Barilla, 173). By turning the act of gathering non-native seeds into an indigenous act, Silko has recontextualized a colonist act into a powerful form of opposition: survival. In a part of the world where water is scarce and cultivation of a good harvest can make the difference between life and death, a plant that may produce a unique food crop is welcome regardless of its country of origin or its appearance. In fact, this acceptance of the seed of outsiders does not begin or end with plants: it is practiced with humans as well.

One of the more brutal acts to occur in the frontier backstory of Gardens is the conception of Sister Salt: she is unambiguously the product of a US soldier raping Grandma Fleet's daughter. And yet "it is important to note here that Salt, despite her mixed ancestry, her 'lighter hair and skin' (Silko, 204), is Sand Lizard. This fictional culture, like many indigenous cultures, is matrilineal and matrilocal; the children are of the mother's people and place" (Roppolo, 81-82). Sister Salt frequently throughout the novel dismisses and demonizes white 
people not simply because she has a rational fear of their oppression, but to reaffirm her mother's work has been done: she is Sand Lizard through and through. When Grandma Fleet dies and her mother goes missing, it is Salt that becomes the matriarch of the dwindling tribe. Even when separated she carries out this duty, having a child of her own with a mixed-raced father (more on him later), and here the same radical embracing of native identity occurs, for according to her "Sand Lizard mothers gave birth to Sand Lizard babies no matter which man they lay with; the Sand Lizard mother's body changed everything to Sand Lizard inside her," (Silko, 204). This is the ultimate shield from any outside concerns of miscegenation or blood quotients: the tribe will endure if even one Sand Lizard woman remains. Even with a quarter of Sand Lizard blood, Salt's son, the "black grandfather" will be culturally and spiritually Sand Lizard, just like his mother. But this total ownership of her indigenous identity is expressed in many other ways, for Sister Salt is forever inventing new avenues of resistance to colonist oppression.

The entirety of the first chapter of the book can be categorized as resistance in its purest sense: Indigo and Salt are raised entirely in Sand Lizard traditions, from tending the garden to making and selling traditional reed baskets. Sister Salt's last words to Indigo before she is taken away to the Indian school is "First Chance you get, run!" (Silko, 69). This advice never seems to pan out for Indigo, whether it be due to the repeated ignorant intervention of Hattie and Edward or for her young age and size making such a feat difficult and inconspicuous. Salt, however, finds much success via resistance after being placed in a reservation on the edge of dam construction. And why shouldn't she? As the eldest daughter raised by two generations of survivors of settler violence, including boundaries as artificial as the tribe they hail from: 
"The creation of the fictional Sand Lizards allows Silko to write against notions of Native American tribes as distant, closed cultural groups or as victims. Her four women are strong, self-reliant, open-minded and spiritually secure," (Grewe-Volpp, 153). By taking Salt away from the gardens, her cultural practices are not nearly as upset as the Indian Police may have intended: she finds a way to profit from a combination of the skills Grandmother Fleet taught her (namely, washing clothes with almost no clean water) and the open sexual practices of the Sand Lizards in a place where opportunities are limited. And far from hoarding this subversive business model, she uses it to build the foundation of a powerfully feminine tribe interested in exploiting the leisure-seeking dam workers the way they themselves have been exploited.

Not once is a character introduced in this novel without applying some cultural context within their character, and with Maytha and Vedna that context seems to be resistance through community building. Like Sister Salt, they see their sex work as a perfectly valid method of funding their return to sustenance farming on land they can call their own (Silko, 477). What's more: they maintain their traditional views on spirituality despite their proximity to a Church and access to a Bible, but will share the bounty of gladioli with formally hostile Christian neighbors, demonstrating an interfaith form of grace. And though they lead a generally pastoral life it is far from idyllic considering the bootlegging and prostitution that paid their way into owning what little lot of land they have. But most telling of all into the nature of the two sisters is their response to soldiers interrupting the Ghost Dancing in Chapter Ten: While Salt and Maytha cursed and spat at the soldiers "Vedna stood her ground and let the Bible fall open, then began to shout the words on the page: “"Even though you make many prayers I will not hear you. Your 
hands are full of blood!"' (Silko, 471). Despite applying the verse as a curse, she engages with colonist forces on their terms with a threat that holds weight to them. Vedna, and to a similar extent Maytha, are willing to adapt themselves to the circumstances around them both for survival and for spiritual growth. However, Silko offers an inversion to this community-driven feminism through perhaps the most unlikely of sympathetic characters.

As stated previously, Hattie commits one of the most extreme acts of resistance depicted in Gardens when she sets fire to Albuquerque in Chapter 10; though it begins as merely setting ablaze her attacker's stable, she is delighted to see that the flame spreads to the homes of his neighbors. In a way, this moment represents the natural conclusion of a character who "lack(s) the self-definition and community orientation provided by meaningful social narratives," ( $\mathrm{Li}$, 25). Hattie has been defined up to this point in relation to two spheres, neither of which strongly connect to a sense of community: a female academic and a botanist's wife. Neither role completely satisfied her need for spiritual actualization, which manifests in taking in Indigo and engaging in increasingly paganistic practices. The ultimate conclusion of this character growth is in the almost ritualistic description of the city burning:

As the flames snaked over to catch the roofs of buildings on either side of the stable, the fire's colors were brilliant- the reds as rich as blood, the blues and whites luminous, and the orange flames as bright as Minerva's gemstone (Silko, 475).

While Vedna and the Christian Indians of Road's End would never dare to commit to such an act of revenge, Hattie can come in as a privileged outsider and cleanse the city of its sins with fire. She punishes the town not only for its crimes against herself, but for the many daily injustices the 
white settlers to this area inflict on the indigenous community that she finds herself increasingly aligned with. This act of extreme resistance is comparable to only one other, more visibly paganistic influence in the novel: The Black Indian of Tampico.

The character of this witch is practically an idealization of resistance: she rebuffs Edward's desire to purchase her meteor irons and the sailors that know of her are terrified of evoking her wrath.In fact, a case could be made that her threats are indeed valid, for she tells Edward that "You cannot buy them (her meteor irons) but you will pay!" (Silko, 90) and while the sailors specifically attribute the storm as her doing, I believe her work extends farther still than that. The orchids he was truly after during his brush with the black Witch are part of the revered flora that Mayans and other Central-American tribes considered sacred (Ossenbach), nevermind Edward's own fatal forays into meteorite collecting in Chapter 9. The novel implies that the misfortunes Edward encounters over the course of the novel are in fact manifestations of a righteous witch enacting vengeance on the predatory capitalist advances of one unlucky, though not at all innocent, white man. Consider this: Citrons are symbolic of everlasting life from Egypt to Eden (Spurrier, 2013), and within a month of attempting to steal samples of them from Italy, he is killed in an accident at the mining site where he intends to harvest his meteor irons. He literally cannot buy them, but he pays the ultimate price for his unbridled colonist entitlement. But the Black Indian is not nearly alone in her intimate connection to nature in her relief from white supremacy; at the heart of this book is a young girl whose cultural redemption is tied to empathic gardening sensibilities. 


\section{A Flower Transplanted, a Mountain Transgressed}

Indigo's very name points to her complicated relationship with nature and settler culture: indigo plants were initially used by indigenous cultures as dyes before being appropriated by Spanish Colonists for economic reasons, only to return to nature and become indigenous in tropical and desert locations (Rembert, 128). This history of the plant species mirrors the history of the child: in her failed resistance, she still finds a way to return to the Old Gardens more or less unconverted by Hattie and Edward's westernized education. The secret to this is her quiet, childlike opposition: she sleeps on the floor, collects seeds, and filters all of her observations of the Western world through her connection to nature and her indigenous experiences. In spite of being all but literally transplanted into every bastion of western civilization, her identity is unshakable: "Indigo, the name of a desert plant, alludes to the younger girl's spiritual rootedness in her native ground. Indigo's name also suggests her relationship to the sacred.” (Ryan, 116). Even during the Masque of the Blue Garden, when she is dressed as a white girl and practicing rules of English etiquette, she "had to laugh at her dark Sand Lizard face in the gilded oval mirror; now a Sand Lizard was loose in the white people's world," (Silko, 161). By subtly going along with the wishes of the white adults around her and playing up her charm, she is able to profit in a very similar way to her elder sister. Her embracing of Native identity may not be as adamant as Salt, but her white caretakers can see it plainly.

Indigo will often contextualize events surrounding her in white society with her upbringing in the Old Garden, often creating moving moments of cognitive dissonance that can be... polarizing, to say the least. One example of this cultural dissonance occurs after Edward is 
detained in Livorno and, in an attempt to calm her down, Indigo tells Hattie stories about how the Indian police brutalized herself and her family, concluding with the cheerful statement "at home people got arrested for no reason all the time. There was nothing to be ashamed of' (Silko, 324). Far from cheering her up, this revelation does two things: firstly, it horrifies Hattie that the cruelty her unofficially-adopted child has completely normalized before meeting her. Less obviously, the implication that even an innocent Indian can be arrested and tied up like an animal stands in cold contrast to the legitimacy of Edward's crime and the hardship his incarceration inflicts on her. What's worse, the selfishness of Edward's crimes is evident in the violent nature of his sample collection: "Seeds are symbols of biological sovereignty and wildness; cuttings represent the transformation of the plant into a commodity. Indigo collects seeds on her travels, but Edward is interested in cuttings" (Barilla, 168). His entitlement to the almighty dollar compels him to steal, to harm the citron as a whole for the sake of the sample, and to create Americanized hybrids that degrade the quality of the original. In contrast, Indigo always receives her seeds as either gifts or lucky finds in wild spaces, and as seeds there is minimal ethical conflict for replanting them, particularly because she does not intend to profit from her collection. Instead, like her Grandmother, Indigo collects seeds for the sake of food and because nurturing plants is a spiritual act for her people; and whereas Edward fails in his smuggling, she manages to bring home her own gifts of Italy with minimal effort.

Indigo's greatest acquisition, and her greatest challenge as a young gardener (at least according to Edward), are the corms of gladiolus given to her by Linda. However, the gladiolus flourished under her care in the desert; this is not surprising if one considers the horticultural 
needs of the plant in question. Natives to South Africa, gladioli do well in well-drained, full sun locations with a thick mulch and a cycle of leaving the cut plant in the ground to rejuvenate future generations of corms (Thomas, 2011); within the Old Gardens and the gardens of the Chemehuevi Sisters, these traits are ideal. The end result is both a practical food source in the form of the corms and a symbolic display of indigenous pride; Indigo's generosity with the corms in fact reflects the symbolism of Gladiolus as the flower of generosity. This act of giving And this is where we see the best possible outcome for opposition in the book: The dominant culture is transformed from a threatening outside influence into something that can be integrated into traditional social constructions. And yet, there is another path of opposition shown in the novel; one that leads down a dark road towards becoming the oppressor in your search for freedom from oppression.

Big Candy, like the Black Indian of Tampico, is a mixed African/Native American man whose aforementioned criminal empire in the desert is built on the noblest of intentions on the surface: he wishes to open his own restaurant in Denver to simultaneously escape poverty and to pursue his passion for cooking. And yet noble or not Imperial it is, for it relies on the capitalist wishes of a white male authority in the general form of his patrons and the specific master-servant relationship he has with foreman Wiley. Tellingly, the foreshadowing that "Greed will be Punished" as described by Delena in her fortune telling seems to not apply to Wylie, whom has the resources and the privilege to start from scratch in Los Angeles after his savings are stolen (Silko, 389); it is only Big Candy's pursuit of Delena (and, perhaps the general attitude of blindly following "The American Dream" as a means of escape) that is portrayed as both 
greedy and perhaps punishable by death. Delena, of course, is meant to be a foil to Candy: a wandering gypsy using dog circuses and well-timed heists for the good of her collective indigenous village in Mexico and her people's revolutionary war against the Mexican government. Though, she goes well beyond this and acts as a meta force of change: "Silko engages this novel as a Trickster/Artist... she is the narrator of the novel and appears as the character Delena who arrives late in the novel as the entrepreneurial and radical leader of a traveling dog circus" (Robins, 38). As an author avatar, Delena's acts of resistance are read as a form of deus ex machina through which the exploitive capitalist wasteland created by the construction of the dam is overturned literally overnight. And more specifically, it is the act of chasing her that we see extreme character development within Big Candy.

While both Big Candy and Delena nearly die of thirst and exertion in their climactic chase through the mountain, Candy loses his driving passion in life along with the water weight. "Even the odor of cooking meat and grease made him feel weak and ill; his passions for new recipes and unusual game or seafood were gone. Wylie wanted him to go to Los Angeles to open a restaurant, but that wasn't possible now" (Silko, 463). And yet, what is possible now (and what the transition on the same page implies) is that Candy will act as a relief driver to Hermosillo to deliver the contraband weapons that Delena has bought with the money she has successfully stolen from him. Indeed, Delena's trickster nature has in a way saved Candy from himself: he is now a part of her resistance after being reborn in the desert. In Candy, Silko is outlining exactly where "opposition" turns into "complacency" and warns that if we only work towards getting ahead by ourselves we will lose our drive one way or another, and perhaps even be further 
awakened to our own subjugation and our own place in dismantling it. And yet, the most dramatic of paradigm shifts in Gardens occurs not in the flow of character arcs but in the dynamic reflections brought about by observing the scenery

\section{The Old Gardens and the New}

The litmus test through which every garden is judged in the narrative is the titular Garden in the Dunes: the Old Gardens of the Sand Lizards. The opening of the Sand Lizard sisters is mirrored by scenes of ecological rebirth as well as a literal rebirth of their ancestors through Sister Salt's "Black Grandfather baby" that suggests that the Sand Lizard way of life is intrinsically tied to the earth via a "language of love" (Roppolo, 88): i.e. a mutual sustenance between the people and their crops. This kind of gardening sensibility is purely utilitarian, and every plant must contribute something edible, craftable, or spiritually nurturing to the gardeners; this contextualizes the Old Garden as a space of resistance through maintaining tribal existence. As stated previously, the gladioli fit into this scheme through their edible corms and their ability to appease the critical eye of Christian neighbors. And yet, Indigo's introduction of these plants to the Native garden proves that her own opposition was not fruitless: she has taken from the white world an aesthetic plant and "indigenized" by recontextualizing it as a part of sustenance farming. But that is not the only addition to the garden that Indigo has contributed: her pets perform a ceremonial duty in the gardens. For the purpose of doing their part, Indigo "Patiently... taught the monkey and the parrot to leave alone the garden plants but to pull the weeds" (Silko, 436). A weed may only be a weed based on the perceptions of the gardener, but this education of her animals shows that Indigo sees an anthropomorphic dignity in their 
intelligence and accordingly passes on the knowledge of her tribe's conceptions of weeding. This is a far leap from their previous experiences in the Eurocentric gardens of Edward and Susan, where they were each caged and regarded as endemic set pieces to a human narrative of the natural world, something of an anthropocentric diorama.

On the very surface, the orchard of the Riverside estate where Indigo finds herself after her first escape attempt seems to fit into the paradigm of the Old Gardens: the oranges and lilacs provide a direct benefit to Edward and Hattie. And yet, their views of horticulture are not nearly as aligned with Indigo's as this taxonomic comparison would imply: "while Edward sought his botanical professional advancement with such plants (revealing an imperialist attitude of the colonial explorer) and Hattie appreciates them for the pleasure they provide, Indigo combines appreciation of their beauty with a practical use" (Bowers, 269). For Edward, botany has been and always will be a financial resource and a means of proving his superiority: even naming the monkey Linnaeus is a subtle insistence that all of life is categorized by the calculated biases of male, European scientists. Hattie, meanwhile, treats this space as a testing ground for a femininity society has forced upon her; her interest to be a good gardener is an extension of becoming a good wife, though she holds off on direct changes when initially there to avoid upsetting the help that actually maintains the garden. So instead she pours her need to be a nurturing influence into the escaped child, the innocent savage that she must protect and feed and clothe, all in spite of the legal repercussions of doing so. Indigo, for her part, reflects these bald-faced exploitations back at them: planning to use first their generosity to regain her strength from her rough interment at "school," and then the train ride from Riverside to Oyster Bay as a 
means of escaping for home yet again. It is only after this attempt is thwarted by the well meaning (yet ignorant all the same) couple and the trio reach New York that these biases begin to reveal themselves with renewed zeal.

It doesn't take a deep literary analysis to determine that Susan's infidelity to her husband and her capricious landscape architecture stem from the same issue: a deep boredom and dissatisfaction with married life. She does not engage in opposition beyond this token selfishness, and thus she is trapped in a cycle of seeking novelty and receiving dissatisfaction while harming or disposing of everything that is inconvenient to her. And yet, her occidental decadence acts as a deep mirror to her guests, particularly for the transformative perspective of the child: "Even in the midst of Susan's party, Indigo is thinking of the Messiah. The moonlight and white blossoms remind her "of the Messiah and his family and all the [ghost] dancers in their white blankets all shimmering in the light reflected off the snow"' (Silko, 196). Indigo is never spoiled by material comforts," (Ryan, 116). In spite of the known loss of the indigenous tribes whose stolen land she currently inhabits, Indigo is overwhelmed by the beauty of the gardens specifically because Susan's fashion sensibilities coincidentally reflect her experiences with the divine. The sacred nature of the garden space, therefore, has not been reduced by its loss of native inhabitants nor the cruel treatment rendered on the transplanted oaks, merely sublimated with western imagery as the image of the Messiah was synthesized with the circle-dance ceremonies as an anti-colonist statement. Edward, fittingly enough, shows a similar immortalizing reverence for the greco-roman statues that are about to be carted off to auction: "Under his black camera cloth he focused the camera lens on the freight wagon loaded with 
marble statues and lead figurines secured by ropes in wooden crates. In the contrasting light, the pale figures piled on one another in the wagon made a macabre image," (Silko, 191). His apprehension is telling: Edward is capturing a memento mori of the literally-toxic idols of romanticism that have contributed to justifying countless oppression. Perhaps he is awakening to the fact that the superiority he counts on for his identity is an ancient, crumbling relic of a bygone era, and perhaps this is why he draws Indigo into the photography session: he must juxtapose the perfect statues against the "savage" indian to maintain his salve of scientific racism. Unfortunately for him, such damage control does not pass with such subtlety on his wife when they reach England.

Aunt Bronwyn is in many ways an older and more enlightened version of Hattie; not only does she seriously engage Indigo's talks of an Indian Messiah (Silko, 264), but she makes the exact international connection between her genius loci standing stones and the black rock of the Ghost Dance that Indigo would have made for herself. This identification with Indigo suggests that she recognizes the parallel between her own struggle to preserve the stones with the indigenous struggle to maintain their culture against the same erasure; they are joined in a morally-binding need to maintain the sovereignty of these formations. Her spiritualism is quite contagious, as "Hattie emerged from this removal (from Indigo) to a happy ending, at least from Silko's point of view, by rejoining Aunt Bronwyn, the eccentric woman in England who tends gardens, eschews the popular culture of her time, and instead uses her money to support archeological digs that investigate pre-Christian (presumably matriarchal) pagan cultures of Europe" (Magoulick, 26). Bronwyn's unconventional ways, from her gardening for her own 
pious sake rather than entertaining a spouse or guests to her whole-hearted embracing of heretical ideology, awakens Hattie to parts of herself that have been restricted by patriarchal and colonial interests in her life. This visit acted as an accelerant that would later flare up in Albuquerque, as the gift of Minerva's gemstone was from the Roman bath house Bronwyn was so interested in preserving. Perhaps that was the intended goal she had in mind when offering to host them, and her recommending a stay with Professora Laura was her way of continuing to cultivate Hattie's newfound need to grow against the grain of her puritan upbringing and selectively Eurocentric husband.

Based on the observation made two paragraphs ago of Edward's morbid fascination with Greco-Roman aesthetic, as well as his goal of gathering citrons from the region, one would assume that Edward would be thrilled to be hosted by an Italian intellectual with whom he can relate. And yet he holds nothing but disdain for Laura's gardening sensibilities, beginning the schism that would lead to his marriage to fall apart: "Edward called the sculpture primitive, but Hattie disagreed; although the clay figures were simple in form, the expression of the mother's body as she cradled her baby in her arms touched Hattie deeply...Hattie wiped the tears away quickly with the back of her hand. Edward would not understand; he'd think she was ill again" (Silko, 300). Edward, so secure in his Empirical (read:Imperial) science and his biased objectivity, can only see the statue for its form; worse still, he mistakes his wife's emotional intelligence for the function of the statue as female hysteria. Despite both identifying as academics and ostensibly marrying for this reason, Edward will never see her perspective as valid were he to recognize it for what it was in the first place. This ties into her reaction when he 
is later caught stealing the citrons, and the specific reason she saw that their marriage would not be sustainable: "It did not seem to occur to him she wanted apologies, not explanations" (Silko, 371). Edward rarely thinks of solutions that may act to humble him, instead choosing to believe that if others can see from his point of view all of his blame will be absolved. How unsurprisingly masculine of an assumption that is! But in truth, his fate was sealed before he was apprehended: Hattie's exposure to happy widows and divorcees living and gardening for themselves alone had already begun to awaken her to Edward's inadequacies. Her resistance to the indifference of Albuquerque was heralded by her opposition to the need of male authority to contextualize her observations for her and to take the examples of Laura, Bronwyn, and especially Indigo in believing in her own observations and values. And while marking the symbolic shifts that occur in European gardens is quite elucidating, there is greater still revelations that can be found back in the indigenous gardens inhabited by the rebellious Sister Salt in her sections of storytelling.

Sometimes, when people are as close to nature as Sister Salt is, their natural instincts call to them in subtle ways; this is what motivates her to take a walk in the desert hours before her premature labor starts. At the end of it, she finds a patch of melons, sunflowers, and chili peppers that signal that "once someone must have had a garden here, and a few seeds replanted themselves just as they did at the old gardens" (Silko, 342). It is in this substitute for her ancestral home, long abandoned by the likely indigenous gardener that once cared for it, where Salt delivers her small, wrinkled baby through a bloody and perilous labor without any assistance. One must wonder if the survival of the baby was not in part thanks to the meal his 
mother partook of, or if it was the connection to indigenous identity that sustained them. This has been theorized before by Kimberly Roppolo:

This connection is emphasized when the "rain cloud ancestors" come to "greet" the baby, knowing that "if not properly welcome, a baby that tiny might give up this world and leave" (Silko, 370) Each new Sand Lizard needs to be shown that they are still connected with their extended Sand Lizard maternal family on this side as well as in the Spirit World, that Birth and Death are part of one cycle (87).

In spite of the mixed race ancestry of Sister Salt and her son, they are elementally enshrined as full members of their tribe, their survival codifying the survival of the Sand Lizard way. The fact that the Sand Lizard life-death cycle is explicitly reincarnation furthers this, particularly Salt's assertion that the baby is her Grandfather reborn: his wife and her Grandmother Fleet are carried on those clouds, one and the same. The US army's attempt to kill him, as well as to exterminate the tribe as a whole, has only managed to defer his resistance onto another generation: whether this is metaphorical or literal is wholly irrelevant, for his upbringing under Salt will become a self-fulfilling prophecy. This is even reflected in the return to the Old Gardens, where the cut down apricot tree and murdered Old Grandfather Snake are supplanted by new seedlings and a granddaughter. And while this garden sustains itself on rare and sacred rains, the Black Grandfather will never know a life without gardens, even before his mother and aunt find themselves back in the Old Gardens.

As fitting as it might have been to have Indigo and Sister Salt to reunite at the Old Gardens, this is not what occurs. Instead "Sister Salt's sojourn near the river comes to an end 
when she and Indigo are reunited. This takes place on property the twins (Maytha and Vedna) purchase from an elderly aunt. From this property they watch as the waters of the river back up behind the new dam... once again, water and the Mother Creator are intrinsically tied" (Purdy, 157). As with Roppolo, Purdy connects the feminine sacred with the rain, and in doing so strengthening the impact of the two sisters reuniting, one as a Mother and the other a reverse-conquistador. The water, in kind, stops at the edge of Maytha and Vedna's property, allowing their crops to flourish where the antagonizing church nearby floods. Their anger is coded as dogmatic jealousy, as “the twins said it didn't matter that the flooded people planted late because the white churchpeople sent them a wagonload of food once a month" (Silko, 450). The price of continued resistance to cultural genocide seems to be constant agrarian work, as both sets of sister are prepared to carry on in this fashion. They may entertain some Judeo-Christian beliefs, in the same way that Maytha and Vedna entertain Indigo's planting of the gladioli corms, but they will only see the value in either in the context of their own indigenous framework. Their years of sustained resistance means they must hold out this caveat of indigenous utilitarianism, and while they cannot see the intrinsic value of the gladiolus the same way Indigo does they still warm up to it in spite of its European nature. In short, Silko's sensibilities on gardens seems to be this: it must nourish its gardeners in return for their upkeep, whether that be literal nourishment or spiritual sustenance.

\section{Conclusion}

To return to the modern relevance of Gardens in the Dunes, resistance and opposition will work differently relative to the situation. Burning down cities may work just fine if you're 
an unassuming white woman from out of town, but clearly that is not an avenue that many people can (or for that matter should) pursue. Instead, smaller resistances (i.e. oppositions) maintained over a longer period of time seem to do the trick, such as Salt profiting from the Dam workers or the Black Witch cursing any white man that looks at her wrong. We must continue to march, to kneel, to stand up in the face of white supremacy and continue to declare "No, your day is done". In other instances, Opposition is more helpful; at least when the opposition is guided towards some selfless goal such as Indigo's seed collecting and not Big Candy's extravagant restaurant idea. In other words, we should focus less on lifting ourselves out of the hole and more on advancing a communal existence. Finally, there is the question of gardening: are we as a society doing enough to not just be good allies to one another in the fight for social justice, but to be good allies to the earth? True, not everyone has the space to garden, but everyone has a choice in how they treat their environment and on the whole we take a lot more than we give. For those that do cultivate plants, there must be a mindfulness paid that the species chosen for our gardens reflect well on our values: either native species or ethically-sourced plants that fit into our respective climates and that provide us with something that sustains us, be it an ingredient or a deeper sense of worth. When such considerations are taken into account, we can begin to address larger issues of social justice outward through the fruits of our physical and empathic labor and perhaps, if not literally then in a broader social sense, we can begin to practice the Ghost Dance the way it was meant to be. 


\section{Works Cited}

Arnold, Ellen, and Leslie Marmon Silko. "Listening to the spirits: An interview with Leslie Marmon Silko." Studies in American Indian Literatures (1998): 1-33.

Barilla, James. "Biological Invasion Discourse and Gardens in the Dunes". Reading Leslie Marmon Silko: Critical Perspectives through Gardens in the Dunes, Association of American University Presses, 2007. Print.

Bowers, Maggie Ann. "Eco-Criticism in a (Post-) Colonial Context and Leslie Marmon Silko's Almanac of the Dead." Towards a Transcultural Future: Literature and Human Rights in a 'Post'-Colonial World (2004).

Burton, Richard DE. Afro-Creole: power, opposition, and play in the Caribbean. Cornell University Press, 1997. Book.

Cummings, Denise K. "' Settling" History: Understanding Leslie Marmon Silko's Ceremony, Storyteller, Almanac of the Dead, and Gardens in the Dunes." Studies in American Indian Literatures (2000): 65-90.

Grewe-Volpp, Christa. "The Machine in the Indigenous Garden: Leslie Marmon Silko's Gardens in the Dunes." Rereading the Machine in the Garden: Nature and Technology in American Culture 34 (2014): 148.

Kehoe, Alice Beck. The Ghost Dance: Ethnohistory and Revitalization. Waveland Press, 2006.

Magoulick, Mary. "Landscapes of Miracles and Matriarchy in Gardens in the Dunes", Reading Leslie Marmon Silko: Critical Perspectives through Gardens in the Dunes, Association of American University Presses, 2007. Print.

Purdy, John. "Water as Leitmotif in Gardens in the Dunes", Reading Leslie Marmon Silko: Critical Perspectives through Gardens in the Dunes, Association of American University Presses, 2007. Print.

Rembert, David H. "The Indigo of Commerce in Colonial North America."Economic Botany 33.2 (1979): 128-134.

Robins, Barbara K., “Tips for Nurturing the Home Garden”, Reading Leslie Marmon Silko: Critical Perspectives through Gardens in the Dunes, Association of American University Presses, 2007. Print. Economic Botany 33.2 (1979): 128-134.

Roppolo, Kimberly, “"We've Got to Get Ourselves Back to the Garden:" Indigenous Views of the Life-Death Cycle as Resistance in Leslie Marmon Silko's Gardens in the Dunes”, Reading Leslie Marmon Silko: Critical Perspectives through Gardens in the Dunes. Association of American University Presses, 2007. Print. 
Ryan, Terre, "The Nineteenth-Century Garden Imperialism, Subsistence, and Subversion in Leslie Marmon Silko's Gardens in the Dunes", Volume 19, 3, Studies in American Indian Literatures, Fall 2007. Print.

Silko, Leslie Marmon, Gardens in the Dunes, Simon and Schuster, 2000. Book.

Spurrier, Jeff. “Growing the Etrog Citron, a Tree Full of Symbolism”, Los Angeles Times, Los Angeles Times, Jun 04, 2013. Web.

Thomas, Robert B. "Gladiolus: How to Plant, Grow, and Care for Gladiolus.” The Old Farmer's Almanac. July 11, 2012. Web. 